\title{
RAGAM BAHASA GAUL KALANGAN REMAJA DI KOTA BENGKULU
}

\author{
Reza Ertika, Dian Eka Chandra W., dan Irma Diani \\ Program Studi Pendidikan Bahasa Indonesia \\ Jurusan Pendidikan Bahasa dan Seni \\ FKIP Universitas Bengkulu \\ Rezaertika28@gmail.com
}

\begin{abstract}
Abstrak
Penelitian ini bertujuan untuk mengetahui bentuk kosakata bahasa gaul dan konteks penggunaan bahasa gaul kalangan remaja di kota Bengkulu. Metode yang digunakan dalam penelitian ini adalah metode deskriptif kualitatif, yaitu metode penelitian yang menghasilkan data deskriptif berupa kata-kata tertulis. Teknik pengumpulan data dalam penelitian ini, yaitu (1) Observasi, (2) Rekaman, (3) Wawancara. Untuk pengolahan data digunakan langkah-langkah berikut (1) Transkripsi Data, (2) Identifikasi Data, (3) Klasifikasi Data, (4) Interpretasi Data, dan (5) Simpulan. Dari hasil penelitian yang dilakukan, diperoleh gambaran bahwa bentuk kosakata bahasa gaul yang digunakan kalangan remaja di kota Bengkulu berupa (1) Nasalisasi $-n g,-a,-d a$, $n a$, -se, -es, -ra, -s, dan -ong, (2) sisipan -ok, (3) metatesis atau walikan, (4) reduplikasi, (5) Bahasa Inggris, dan (6) pola acak. Kosakata bahasa gaul remaja digunakan untuk menyampaikan gagasan, ide, dan pendapat kepada sesama remaja. Pengguna kosakata gaul ini adalah kalangan remaja di kota Bengkulu yakni mahasiswa hingga remaja yang sudah bekerja yang berusia 15 tahun sampai 24 tahun. Konteks yang digunakan remaja tersebut adalah pada saat situasi santai dan akrab, dan ketika sedang berkumpul membicarakan seputar kehidupan atau lingkungan sosial mereka melalui media bahasa lisan. Konteks situasi dalam penggunaan kosakata bahasa gaul yaitu saat sedang berkumpul di kos-kosan, di rumah, di kampus, dan tempat-tempat yang tidak terduga.
\end{abstract}

\section{Kata kunci : Ragam bahasa, bahasa gaul, remaja.}

\begin{abstract}
This study aims to determine the form of slang language vocabulary and the context of the use of slang among teenagers in the city of Bengkulu. The method used in this research is descriptive qualitative method, which is a research method that produces descriptive data in the form of written words.Data collection techniques in this study, namely (1) Observation, (2) Records, (3) Interviews. For data processing, the following steps are used (1) Data Transcription, (2) Data Identification, (3) Data Classification, (4) Data Interpretation, and (5) Conclusion. From the results of the research conducted, it was obtained an illustration that the form of slang vocabulary used by adolescents in the city of Bengkulu was (1) Nasalization -ng, -a, -da, -na, -se, -es, -ra, -s, and -ong, (2) insertion -ok, (3) metathesis or walik, (4) reduplication, (5) English, and (6) random patterns. Teenage slang vocabulary is used to convey ideas and opinions to fellow teenagers. Users of this slang vocabulary are teenagers in the city of Bengkulu, namely
\end{abstract}


students to teenagers who have worked who are 15 years-24 years old. The context used by adolescents is when the situation is relaxed and intimate, and when they are gathered talking about their life or social environment through the spoken language. The context of the situation in the use of slang vocabulary is when gathering in boarding houses, at home, on campus, and places that are not unexpected.

\section{Keywords : Variety of languages, slang language, teenagers.}

\section{PENDAHULUAN}

Bahasa merupakan suatu alat komunikasi yang digunakan untuk berinteraksi dalam berbagai konteks dan makna. Bahasa digunakan oleh berbagai golongan masyarakat maupun kelompok sosial untuk menyampaikan gagasan, ide, pendapat, serta untuk saling bertukar pendapat.

$$
\text { Lapasau \& Arifin (2016:1) }
$$
mengemukakan bahwa bahasa adalah sistem lambang bunyi yang arbitrer dan digunakan oleh masyarakat untuk berkomunikasi atau berinteraksi. Dari definisi tersebut dapat dikatakan bahwa bahasa harus bersistem, berwujud simbol yang kita lihat dan kita dengar dalam lambang, serta bahasa digunakan oleh masyarakat untuk berkomunikasi. Bahasa digunakan manusia dalam segala aktivitas kehidupan. Dengan demikian, bahasa merupakan hal yang paling hakiki dalam kehidupan manusia. Sosiolinguistik mempelajari hubungan antara bahasa dan masyarakat. Mereka tertarik untuk menjelaskan mengapa kita berbicara secara berbeda dalam konteks sosial yang berbeda, dan mereka perduli untuk mengidentifikasi fungsi sosial bahasa dan cara-cara itu digunakan untuk menyampaikan makna sosial. Memeriksa cara orang menggunakan bahasa dalam konteks sosial yang berbeda memberikan banyak informasi tentang cara kerja bahasa, serta tentang hubungan sosial dalam suatu komunitas, dan cara orang memberi sinyal aspek identitas sosial mereka melalui bahasa mereka (Holmes, 2001:1).

Variasi bahasa adalah sejenis ragam bahasa yang pemakaiannya disesuaikan dengan fungsi dan situasinya, tanpa mengabaikan kaidah-kaidah pokok yang berlaku dalam bahasa yang bersangkutan. Hubungan antara faktor-faktor sosiosituasional di dalam pemakaian bahasa, serta terjadinya saling mempengaruhi antara kaidah-kaidah gramatikal dan norma-norma pemakaian sesuai dengan fungsi dan situasinya (Padmadewi et al. 2014:7-8).

Salah satu variasi bahasa yang ada adalah ragam bahasa gaul. Secara lingual perbedaan bahasa remaja dengan anggota kelompok masyarakat yang lain dapat dilihat dalam berbagai tataran kebahasaannya, seperti tataran fonologi, tataran morfologi, tataran sintaksis, dan tataran leksikon, bahkan mungkin tataran yang lebih tinggi (Wijana, 2010:6).

Hermanto (dalam Mastuti, 2008:70) menyatakan bahawa bahasa yang digunakan masyarakat terutama kalangan selebritis dan kalangan muda sebagai bahasa santai dalam komunikasi sehari-hari untuk menambah rasa keakraban dan keintiman di antara mereka.

Awalnya istilah-istilah dalam bahasa gaul ini untuk merahasiakan isi obrolan dalam komunitas tertentu, tetapi karena sering digunakan di luar komunitasnya, lama-kelamaan istilah-istilah tersebut menjadi bahasa sehari-hari. 
Ragam bahasa gaul remaja memiliki ciri khusus, yaitu : singkat, lincah, dan kreatif. Kata-kata yang digunakan cenderung pendek, sementara kata yang agak panjang akan diperpendek melalui proses morfologi dan menggantinya dengan kata lain yang lebih pendek.

Kosakata bahasa gaul yang berkembang belakangan ini sering tidak beraturan atau tidak mengikuti kaidah. Sehingga setiap kali muncul istilah baru penggunanya perlu menghafalnya. Mmisalnya untuk sebuah lawakan yang tidak lucu disebut garing, jayus atau jasjus. Berbeda dengan bahasa prokem yang populer pada tahun 1970-an, misalnya kata bokap merupakan kata bentukan dari kata bapak (Mastuti, 2008:45).

Berdasarkan beberapa pernyataan di atas dapat disimpulan bahwa bahasa gaul merupakan salah satu variasi bahasa yang sengaja diciptakan dan digunakan khususnya oleh kalangan remaja untuk meningkatkan keakraban dan eksistensi kelompok mereka.

Pada penelitian ini, penulis akan meneliti konteks penggunaan kosakata bahasa gaul di kalangan remaja kota Bengkulu. Penulis memilih remaja karena bahasa gaul umumnya digunakan di kalangan remaja. Ragam tutur remaja juga lebih terkesan unik dan bervariasi, bahkan sulit dimengerti oleh orang lain yang tidak menuturkan bahasa gaul tersebut, sehingga menimbulkan kesenjangan komunikasi di antara remaja yang menuturkan bahasa gaul dan orang-orang di sekitar yang kesulitan memahami cara berbahasa remaja saat ini.

Terciptanya kosakata bahasa gaul juga seringkali mengalami perubahan bentuk yang unik dan sulit dipahami. Hal ini merupakan bentuk kreativitas berbahasa di kalangan remaja. Perubahan bentuk kosakata bahasa gaul remaja di kota Bengkulu yang unik dan seringkali sulit dimengerti oleh orang lain yang tidak menuturkan bahasa gaul tersebut membuat penulis tertarik untuk melakukan penelitian dengan judul "Ragam Bahasa Gaul Kalangan Remaja di Kota Bengkulu".

\section{METODE}

Metode yang digunakan dalam penelitian ini adalah metode deskriptif kualitatif. Sumber data dalam penelitian ini adalah ujaran atau tuturan remaja yang ada di kota Bengkulu, yaitu kalangan mahasiswa dan kalangan remaja yang telah bekerja dengan kisaran usia 15 tahun sampai 24 tahun. Sedangkan datanya adalah ujaran atau tuturan yang mengandung bahasa gaul. Penelitian ini dilakukan kurang lebih 1 bulan dengan 3 teknik pengumpulan data, yaitu transkripsi data, identifikasi data, klasifikasi data, interpretasi data, dan simpulan.

\section{HASIL DAN PEMBAHASAN}

Ragam bahasa gaul kalangan remaja di kota Bengkulu dapat dideskripsikan melalui bentuk dan konteks penggunaan bahasa seperti sebagai berikut :

\section{A. Bentuk Kosakata Bahasa Gaul Remaja}

\section{Bentuk Nasalisasi $+n g$}

Bentuk kosakata gaul nasalisasi $+n g$ yang ditemukan dalam penelitian ini adalah: ngosong, ngegas, ngekor, ngetrip, ngaret, ngepoi, nguli, dan ngemall. Pembentukan kosakata gaul tipe ini adalah dengan proses nasalisasi. Nasalisasi berasal dari kata nasal yang berarti bersangkutan dengan bunyi bahasa yang dihasilkan dengan mengeluarkan udara melalui hidung, yaitu $m, n, n g$, dan $n y$, kemudian diberi imbuhan -isasi menjadi nasalisasi berarti pelepasan udara melalui hidung pada waktu bunyi bahasa dihasilkan. Pada kosakata bahasa gaul tipe ini, kata dasar mengalami proses nasalisasi dengan menambahkan awalan $+n g$ pada kata dasar, seperti pada beberapa data berikut : 
a) /ngosong/ [kosong] $\rightarrow$ ng + kosong

b) /ngegas/ [gas] $\rightarrow$ ng + gas

c) /ngekor/ [ekor] $\rightarrow$ ng + ekor

\section{Bentuk Nasalisasi $+a$}

Bentuk kosakata gaul nasalisasi $+a$ yang ditemukan dalam penelitian ini adalah: udema, duta, sabara, bebala, dan mantana. Pembentukan kosakata gaul tipe ini adalah dengan proses nasalisasi. Nasalisasi berasal dari kata nasal yang berarti bersangkutan dengan bunyi bahasa yang dihasilkan dengan mengeluarkan udara melalui hidung, yaitu $m, n, n g$, dan $n y$, kemudian diberi imbuhan -isasi menjadi nasalisasi berarti pelepasan udara melalui hidung pada waktu bunyi bahasa dihasilkan. Pada kosakata bahasa gaul tipe ini, kata dasar mengalami proses nasalisasi dengan menambahkan akhiran $+a$ pada kata dasar, seperti pada beberapa data berikut:

a) /udema/ [udem/sudah] $\rightarrow$ udem + a

b) /duta/ [duit/uang] $\rightarrow$ duit + a

c) /sabara/ [sabar] $\rightarrow$ sabar + a

\section{Bentuk Nasalisasi $+d a$}

Bentuk kosakata gaul nasalisasi $+d a$ yang ditemukan dalam penelitian ini adalah: nanda, belda, dan lambada. Pembentukan kosakata gaul tipe ini adalah dengan proses nasalisasi. Nasalisasi berasal dari kata nasal yang berarti bersangkutan dengan bunyi bahasa yang dihasilkan dengan mengeluarkan udara melalui hidung, yaitu $m, n, n g$, dan $n y$, kemudian diberi imbuhan -isasi menjadi nasalisasi berarti pelepasan udara melalui hidung pada waktu bunyi bahasa dihasilkan. Pada kosakata bahasa gaul tipe ini, kata dasar mengalami proses nasalisasi dengan menambahkan akhiran $+d a$ pada kata dasar, seperti pada data berikut :
a) /nanda/ [nanti] $\rightarrow$ nanti + da
b) /belda/ [beli] $\rightarrow$ beli + da
c) /lambada/ [lambat] $\rightarrow$ lambat + da

\section{Bentuk Nasalisasi $+n a$}

Bentuk kosakata gaul nasalisasi $+n a$ yang ditemukan dalam penelitian ini adalah: sarona dan marana. Pembentukan kosakata gaul tipe ini adalah dengan proses nasalisasi. Nasalisasi berasal dari kata nasal yang berarti bersangkutan dengan bunyi bahasa yang dihasilkan dengan mengeluarkan udara melalui hidung, yaitu $m, n, n g$, dan $n y$, kemudian diberi imbuhan -isasi menjadi nasalisasi berarti pelepasan udara melalui hidung pada waktu bunyi bahasa dihasilkan. Pada kosakata bahasa gaul tipe ini, kata dasar mengalami proses nasalisasi dengan menambahkan akhiran +na pada kata dasar, seperti sebagai berikut:

a) /sarona/ [saro /susah] $\rightarrow$ saro + na

b) /marana/ [marah] $\rightarrow$ marah + na

\section{Bentuk Nasalisasi + se}

Bentuk kosakata gaul nasalisasi + se yang ditemukan dalam penelitian ini adalah: apose, manose, sapose, dimanose, dan ngapose. Pembentukan kosakata gaul tipe ini adalah dengan proses nasalisasi. Nasalisasi berasal dari kata nasal yang berarti bersangkutan dengan bunyi bahasa yang dihasilkan dengan mengeluarkan udara melalui hidung, yaitu $m, n, n g$, dan $n y$, kemudian diberi imbuhan -isasi menjadi nasalisasi berarti pelepasan udara melalui hidung pada waktu bunyi bahasa dihasilkan. Pada kosakata bahasa gaul tipe ini, kata dasar mengalami proses nasalisasi dengan menambahkan akhiran +se pada kata dasar, seperti pada beberapa data berikut:

a) /apose/ [apo/apa] $\rightarrow$ apo + se

b) /manose/ [mano/mana] $\rightarrow$ mano + se

c) /sapose/ [sapo/siapa] $\rightarrow$ sapo + se

\section{Bentuk Nasalisasi +es}

Bentuk kosakata gaul nasalisasi +es yang ditemukan dalam penelitian ini adalah: mejes, bengkes, ngines, jalnes, endes, dan leges. Pembentukan kosakata gaul tipe ini adalah dengan proses 
nasalisasi. Nasalisasi berasal dari kata nasal yang berarti bersangkutan dengan bunyi bahasa yang dihasilkan dengan mengeluarkan udara melalui hidung, yaitu $m, n, n g$, dan $n y$, kemudian diberi imbuhan -isasi menjadi nasalisasi berarti pelepasan udara melalui hidung pada waktu bunyi bahasa dihasilkan. Pada kosakata bahasa gaul tipe ini, kata dasar mengalami proses nasalisasi dengan menambahkan akhiran +es pada kata dasar, seperti pada beberapa data berikut:

a) /mejes/ [meja] $\rightarrow$ meja + es

b) /bengkes/ [bengkel] $\rightarrow$ bengkel + es

c) /ngines/[nginap] $\rightarrow$ nginap + es

\section{Bentuk Nasalisasi + ra}

Bentuk kosakata gaul nasalisasi +ra yang ditemukan dalam penelitian ini adalah: fotra, belajra, nontra, motra, bentra, nutra, dan jawara. Pembentukan kosakata gaul tipe ini adalah dengan proses nasalisasi. Nasalisasi berasal dari kata nasal yang berarti bersangkutan dengan bunyi bahasa yang dihasilkan dengan mengeluarkan udara melalui hidung, yaitu $m, n, n g$, dan $n y$, kemudian diberi imbuhan -isasi menjadi nasalisasi berarti pelepasan udara melalui hidung pada waktu bunyi bahasa dihasilkan. Pada kosakata bahasa gaul tipe ini, kata dasar mengalami proses nasalisasi dengan menambahkan akhiran +ra pada kata dasar, seperti pada beberapa data berikut :

a) /fotra/ [foto] $\rightarrow$ foto + ra

b) /belajra/ [belajra] $\rightarrow$ belajar + ra

c) /nontra/ [nonton] $\rightarrow$ nonton + ra

\section{Bentuk Nasalisasi $+s$}

Bentuk kosakata gaul nasalisasi $t s$ yang ditemukan dalam penelitian ini adalah: maks, sans, dan metes. Pembentukan kosakata gaul tipe ini adalah dengan proses nasalisasi. Nasalisasi berasal dari kata nasal yang berarti bersangkutan dengan bunyi bahasa yang dihasilkan dengan mengeluarkan udara melalui hidung, yaitu $m, n, n g$, dan $n y$, kemudian diberi imbuhan -isasi menjadi nasalisasi berarti pelepasan udara melalui hidung pada waktu bunyi bahasa dihasilkan. Pada kosakata bahasa gaul tipe ini, kata dasar mengalami proses nasalisasi dengan menambahkan akhiran $+s$ pada kata dasar, seperti sebagai berikut :

a) /maks/ [makasih] $\rightarrow$ mak $+\mathrm{s}$

b) /sans/ [santai] $\rightarrow$ san $+s$

c) /metes/ [mete/pacar] $\rightarrow$ mete $+s$

\section{Bentuk Nasalisasi +ong}

Bentuk kosakata gaul nasalisasi +ong yang ditemukan dalam penelitian ini adalah: lapsong, najong, belenjong, beyong, endong, dan dendong. Pembentukan kosakata gaul tipe ini adalah dengan proses nasalisasi. Nasalisasi berasal dari kata nasal yang berarti bersangkutan dengan bunyi bahasa yang dihasilkan dengan mengeluarkan udara melalui hidung, yaitu $m, n, n g$, dan $n y$, kemudian diberi imbuhan -isasi menjadi nasalisasi berarti pelepasan udara melalui hidung pada waktu bunyi bahasa dihasilkan. Pada kosakata bahasa gaul tipe ini, kata dasar mengalami proses nasalisasi dengan menambahkan akhiran +ong pada kata dasar, seperti pada beberapa data berikut :
a) /lapsong/ [lapar] $\rightarrow$ lapar + ong
b) /najong/ [najis] $\rightarrow$ najis + ong
c) /belenjong/ [belanja] $\rightarrow$ belanja + ong

\section{Bentuk Sisipan -ok}

Bentuk kosakata gaul sisipan -ok yang ditemukan dalam penelitian ini adalah: plokis, spokat, dan rokum. Pembentukan kosakata gaul tipe ini adalah dengan menambahkan sisipan kata -ok di tengah bentuk dasar yang telah disusutkan, seperti data sebagai berikut :
a) /plokis/ [polisi] $\rightarrow \mathrm{pl}+\mathrm{ok}+$ is
b) /spokat/ [sepatu] $\rightarrow$ sp + ok + at
c) /rokum/ [rumah] $\rightarrow$ r + ok + um 


\section{Bentuk Metatesis atau Walikan}

Bentuk kosakata gaul metatesis yang ditemukan dalam penelitian ini adalah: dita, jula, dija, hayap, yoi, kubis, tabo, mola, loka, bais, ipa, saip, takis, tura, edi, saik, kuy, pasra, sabi, sobek, cotba, kerok, somase, naracap, maya, darban, polkis, woles, dan lumbe. Metatesis atau walikan merupakan pembentukan kata dengan membalikkan fonem-fonem dalam kata (ragam walikan). Aturan umum dalam bahasa ini adalah, dasarnya bisa bahasa Jawa atau bahasa Indonesia. Kata-kata "dibaca" menurut urutan fonem dari belakang, dibaca terbalik atau dapat divariasikan dengan menyisipkan bunyibunyi tertentu atau merubah bunyi-bunyi tertentu dalam kata yang telah dibalik sebelumnya.

\section{Bentuk Abreviasi}

Kosakata gaul berupa abreviasi yang ditemukan dalam penelitian ini terdapat tiga bentuk, yaitu singkatan, penggalan dan akronim. Bentuk singkatan yang ditemukan adalah: OTW (On The Way), GWS (Get Well Soon), VC (Video Call), LDR (Long Distance Relationship), ASAP (As Soon As Possible), PHP (Pemberi Harapan Palsu), PK (Penjahat Korek), ATP (Aksi Tebar Pesona), CCDT (Cak Cak Dak Tau), dan DL (Derita Lo). Bentuk penggalan yang ditemukan adalah : jan (jangan), bro (brother), ngap (ngapo), man (mano), say(sayang), sum(sumpah), sist (sister), beb (baby/bebi), halu (halusinasi), ap (apa), insom (insomnia), tepar (terkapar) dan cito (cerito). Bentuk akronim yang ditemukan adalah : aplok (apo lokak), matlok (mati lokak), maksur (makan surang), b ajo (biaso ajo), ningpa (pening palak), carlok (cari lokak), imut (itam mutung), bigos (biang gosip), semampai (semeter dak nyampai), jadian (jadi pacaran), ultah (ulang tahun), mager (malas gerak), malming (malam minggu), ngofe (ngopi café), kudet (kurang update), dempo (demi apo), kopdar (kopi darat), jamber (jam berapa), kece (keren cekali), ramuk (racun nyamuk), hadija (hati-hati di jalan), emeng (emang ngapo), naklok (nak lokak), magalarak (makan galak malas gerak), cogan (cowok ganteng), salting (salah tingkah), cibong (cino Lebong), cakmna (cak mano), jones (jomblo ngenes), elit (ekonomi sulit), ombe (omong bae), samjo (samo ajo), kamse (kampungan sekali), alay (anak layangan), caper (cari perhatian), makir (malas mikir), nofi (nonton film), gaje (gak jelas), ember (emang bener), emker (emang keren), pengacara (pengangguran banyak acara), juskid (just kidding), gercang (gerak gacang), sosmed (sosial media), lamse (lama sekali), samtu (sama tahu), baldus (balik dusun), koper (korban perasaan/persahabatan), japri (jalur pribadi), nyarlok (nyari lokak), dan diman (di mano).

\section{Bentuk Reduplikasi}

Bentuk kosakata gaul Reduplikasi yang ditemukan dalam penelitian ini adalah: cabe-cabean dan yoi-yoi. Reduplikasi adalah proses morfologis yang mengulang bentuk dasar, baik secara keseluruhan, sebagian, maupun disertai dengan perubahan bunyi. Proses pembentukan kosakata gaul berupa reduplikasi sebagai berikut:

a) cabe-cabean $\rightarrow$ kata dasar [cabe] diberi pengulangan kemudian diberi akhiran -an b) yoi-yoi $\rightarrow$ kata dasar [iya-iya].

\section{Penggunaan Istilah Asing (Bahasa Inggris)}

Selain menggunakan bahasa gaul berupa nasalisasi, sisipan kata -ok, metatesis atau walikan dan abreviasi, remaja di Kota Bengkulu juga menggunakan istilah asing (bahasa Inggris) sebagai bahasa pergaulan sehari-hari. kosakata gaul Bahasa Inggris yang ditemukan dalam penelitian ini adalah : war, newbie, spik, 
free, upload, friendzone, surprise, fix, antimainstream, mainstream, goals, weekend, squad, playboy, stalking, minus, terthebest, sosweet, relationship goals, go public, posting, zonk, satnite, standby, keep calm, ontime, start, full, join, share, promot, dan support.

Kosakata gaul yang merupakan bahasa Inggris tersebut tidak dapat dijelaskan kaidah morfologisnya, karena makna dari kosakata gaul tersebut sama dengan makna yang sesungguhnya. Bahasa tersebut digunakan karena sebagian remaja dapat dengan mudah mengakses media elektronik maupun media sosial yang biasa menggunakan bahasa asing (Inggris). Hal tersebut menyebabkan remaja dapat dengan mudah menyerap bahasa asing tersebut dalam kehidupan sehari-hari, sehingga seringkali digunakan untuk bahasa pergaulan.

\section{Pola Acak}

Dari beberapa data berupa bahasa gaul yang telah penulis temukan selama penelitian, terdapat beberapa kata yang tidak diketahui bagaimana proses pembentukannya, seperti pada kosakata gaul yang menggunakan pola acak. Bentuk kosakata gaul menggunakan pola acak yang ditemukan dalam penelitian ini adalah :uap, secaro, pecah, masuk, gabut, cabik, yono, kecap, anjay, mahip, warnik, kenjey, jauhari, kecik, buntu, galau, ditikung, gamang, nembak, boring, nongki, kongkow, bosku, bocor, rempong, gampil, cen, gebet, jambu, badai, udin, boil, cius, lebeh, ngakak, jijay, cucok, cau, dongkol, inaya, dese, dan mersedes.

\section{B. Konteks Penggunaan Kosakata Gaul Remaja}

Pada penelitian ini penulis mengamati beberapa konteks situasi yaitu : (1) pada saat sedang berkumpul di koskosan, (2) pada saat berada di rumah, (3) pada saat berada di kampus Universitas
Bengkulu, (4) pada saat di tempat-tempat yang tidak terduga (di jalan, di warung, di pantai, dan Sport Centre Bengkulu). Konteks penggunaan kosakata gaul ini berhubungan erat dengan kegiatan sehari-hari remaja, seperti masalah percintaan yang digunakan untuk menyampaikan sebuah pendapat maupun informasi serta perasaan terhadap orang lain, masalah pekerjaan yang digunakan untuk menanyakan lowongan pekerjaan yang tersedia, masalah kuliah yang digunakan untuk memperoleh informasi mengenai kegiatan perkuliahan serta berbagai hal yang menyangkut kegiatan perkuliahan, selanjutnya membuat rencana yang telah disepakati bersama untuk melakukan suatu kegiatan, dan keadaan sosial yang ada di sekitar mereka digunakan untuk menyampaikan pendapat pribadi terhadap suatu hal atau apapun yang mereka lihat di lingkungan sosialnya.

Bahasa gaul yang digunakan kalangan remaja di kota Bengkulu ini memiliki keunikan tersendiri. Selain keunikan bahasa-bahasa yang dikreasikan dari bahasa Indonesia, ada juga beberapa kosakata bahasa gaul yang mereka kreasikan dan gunakan dari bahasa daerah Bengkulu.

\section{PENUTUP}

Simpulan

1. Ada enam bentuk bahasa gaul yang digunakan remaja di kota Bengkulu, seperti: a) nasalisasi, b) sisipan, c) abreviasi, d) reduplikasi, e) metatesis atau walikan, f) bahasa Inggris, dan g) pola acak. Bahasa gaul yang digunakan remaja beragam tergantung pengalaman dan pengetahuan yang dimiliki dalam berbahasa.

2. Dalam penelitian ini penulis memperoleh beberapa konteks situasi yaitu : (1) pada saat sedang berkumpul di kos-kosan, (2) pada saat berada di rumah, (3) pada saat 
berada di kampus Universitas Bengkulu, (4) pada saat di tempattempat yang tidak terduga (di jalan, di warung, di pantai, dan Sport Centre Bengkulu).

3. Konteks penggunaan kosakata gaul ini berhubungan erat dengan kegiatan sehari-hari remaja, seperti masalah percintaan yang digunakan untuk menyampaikan sebuah pendapat maupun informasi serta perasaan terhadap orang lain, masalah pekerjaan yang digunakan untuk menanyakan lowongan pekerjaan yang tersedia, masalah kuliah yang digunakan untuk memperoleh informasi mengenai kegiatan perkuliahan serta berbagai hal yang menyangkut kegiatan perkuliahan, selanjutnya membuat rencana yang telah disepakati bersama untuk melakukan suatu kegiatan, dan keadaan sosial yang ada di sekitar mereka digunakan untuk menyampaikan pendapat pribadi terhadap suatu hal atau apapun yang mereka lihat di lingkungan sosialnya.

\section{Saran}

1. Untuk pengguna bahasa gaul, diharapkan penggunaan bahaa gaul tersebut tidak meggeser fungsi bahasa Indonesia, namun dapat menambah perbendaharaan kosakata serta menambah kreatifitas kalangan remaja untuk menciptakan istilah baru.

2. Bagi pengguna bahasa gaul, diaharapkan penggunaan bahasa gaul tersebut disesuaikan dengan situasi dan kondisi yang ada.

\section{DAFTAR PUSTAKA}

Holmes, J. 2001. An Introduction to Sociolinguistics Second Edition. England: Pearson Education Limited.

Lapasau, M \& Zaenal Arifin. 2016. Sosiolinguistik. Tangerang: PT Pustaka Mandiri.

Mastuti, Indari. 2008. Bahasa Baku vs Bahasa Gaul. Jakarta: Hi-Fest Publishing.

Padmadewi, N. et al. 2014. Sosiolinguistik. Yogyakarta : Graha Ilmu.

Wijana, I Dewa Putu. 2010. Bahasa Gaul Remaja Indonesia. Yogyakarta: Aditya Media Publishing. 